\title{
Composition of gas from pyrolysis of Estonian oil shale with various sweep gases
}

\author{
Sepehr Mozaffari*, Oliver Järvik, Zachariah Steven Baird
}

Department of Energy Technology, Tallinn University of Technology, Ehitajate tee 5, 19086 Tallinn, Estonia

Received 12.02.2021, accepted 23.07.2021, available online 10.09.2021

\begin{abstract}
Studying the evolution of gas during the decomposition process of oil shale provides information about the changes of its composition, as well as an understanding of the mechanism of the pyrolysis process. Earlier mainly the $\mathrm{CO}_{2}$ atmosphere was used to observe the effect of the sweep gas on the production of pyrolysis products. In the current study, the Fischer assay method was used to analyze the pyrolysis of Estonian kukersite oil shale with $\mathrm{CO}_{2}, \mathrm{CO}_{2} /$ steam, $\mathrm{N}_{2}$ and $\mathrm{N}_{2} /$ steam sweep gases. The gaseous products were collected offline using a sample bag. Gas chromatography $(G C)$ was performed to investigate the evolution of $\mathrm{C}_{1}-\mathrm{C}_{3}$ gases, $\mathrm{H}_{2}, \mathrm{CO}_{2}$ and $\mathrm{CO}$. Subsequently, the results from each test were analyzed and compared. It was shown that in comparison with $\mathrm{N}_{2}$, pyrolysis in $\mathrm{CO}_{2}$ increased the production of alkanes and hydrocarbon (HC) gases. Also, the generation of $\mathrm{CH}_{4}$ and $\mathrm{CO}$ gases was enhanced with $\mathrm{CO}_{2}$, while the concentration of $\mathrm{H}_{2}$ in the pyrolysis gas did not significantly change with either environment. The tests carried out in the presence of steam showed that unlike the $\mathrm{N}_{2}$ atmosphere, $\mathrm{CO}_{2}$ /steam decreased the production of total hydrocarbons, $\mathrm{H}_{2}, \mathrm{CO}_{2}$ and $\mathrm{CO}$.
\end{abstract}

Keywords: Estonian kukersite oil shale, Fischer assay, pyrolysis, gas evolution.

\section{Introduction}

Compared with other energy sources such as coal and biomass, oil shale is considered to have great potential due to its large known deposits [1]. In addition to serving as an alternative fuel, utilization of oil shale may help keep the balance between energy production and consumption, ensure energy security and benefit countries economically [2]. As a result, the oil shalebased energy production has been acquiring importance in several countries

\footnotetext{
* Corresponding author: e-mail sepehrmozaffari@taltech.ee

(C) 2021 Authors. This is an Open Access article distributed under the terms and conditions of the Creative Commons Attribution-NonCommercial 4.0 International License (http://creativecommons.org/licenses/by-nc/4.0/).
} 
to meet their energy demands [3]. Estonia, for instance, has been producing heat, electricity and power as well as diesel fuel from oil shale for almost a century already, while its respective reserves make up only $1.1 \%$ of the world reserves [4]. However, the continual use of fossil fuels causes an increase in the emission of greenhouse gases into the environment, which leads to climate change [5]. Studying various aspects of the processing of oil shale would be helpful to assess and mitigate the environmental risks [6]. In light of these reasons, investigating alternative fuels has raised interest among researchers and accordingly, abundant analysis has been done on shale oil derived from oil shale pyrolysis. However, detailed analyses of and data about the shale gas from pyrolysis are quite rare. The yields and concentrations of pyrolysis gases are important parameters to learn about the quality of the shale gas produced. Data on shale gas can be helpful to give a better understanding about the chemistry related aspects of gas and oil production [7]. This, in fact, depends on many factors such as the final temperature, residence time, heating rate, production approach applied, oil shale characteristics, condenser used, etc. Since the decomposition of kerogen and conversion to oil take place mainly at temperatures below $500{ }^{\circ} \mathrm{C}$, studying the evolution of gas gives more information about its composition as well as the mechanism of the decomposition process. The analysis of oil yield is provided in the first part of the study.

In this paper, the concentrations of $\mathrm{H}_{2}, \mathrm{CO}, \mathrm{CO}_{2}$ and $\mathrm{C}_{1}-\mathrm{C}_{3}$ hydrocarbons (HC) in the gaseous product, as well as the evolution of these gases at different temperatures during pyrolysis are reported. The results give evidence of the dependency of the release of the gases on temperature.

\section{Experimental section}

\subsection{Fischer assay}

In pyrolysis experiments, a kukersite oil shale sample obtained from the Ojamaa mine located in northeast Estonia was used. The experiments were carried out in a Fischer assay retort. The $50 \mathrm{~g}$ oil shale sample was crushed to a particle size of 500-710 $\mu \mathrm{m}$. The pyrolysis tests were conducted using the following sweep gases: $\mathrm{CO}_{2}, \mathrm{CO}_{2} /$ steam, $\mathrm{N}_{2}$ and $\mathrm{N}_{2}$ /steam. These sweep gases were introduced into the retort at a rate of $21 \mathrm{ml} / \mathrm{min}$ and in steam tests the gas and water flow rates were 10 and $0.1 \mathrm{ml} / \mathrm{min}$, respectively. The sweep gases were injected into the system one hour before the pyrolysis began to ensure that the air was totally flushed out of the retort. Then, the retort was heated up to $500{ }^{\circ} \mathrm{C}$ at $10{ }^{\circ} \mathrm{C} / \mathrm{min}$ and to $520{ }^{\circ} \mathrm{C}$ at $1{ }^{\circ} \mathrm{C} / \mathrm{min}$ and held at $520{ }^{\circ} \mathrm{C}$ for 20 minutes. The total run took $90 \mathrm{~min}$. Steam tests used a small heater to convert the injected water into steam before it reached the retort. 


\subsection{Gas chromatography}

A Shimadzu GC-2014 gas chromatograph with a thermal conductivity detector (GC-TCD) and a valve system was used to analyze the release of various gases in a single run. The amounts of $\mathrm{O}_{2}, \mathrm{~N}_{2}$ and $\mathrm{CO}$ were determined using a $3 \mathrm{~m}$ packed column with a $5 \AA$ molecular sieve (OD 1/8", ID $2 \mathrm{~mm}, 80 / 100 \mathrm{mesh}$ ), while a 9 m 25\% DC-200/Shimalite packed column (60/80 mesh, OD 1/8", ID $2 \mathrm{~mm}$ ) was employed to determine the amount of $\mathrm{CO}_{2}$. Determining the amounts of the aforementioned gases was possible by calibration. The calibration of $\mathrm{GC}$ was done by injecting $3 \mathrm{ml}$ of gas with different concentrations of $\mathrm{O}_{2}, \mathrm{~N}_{2}, \mathrm{CO}$ and $\mathrm{CO}_{2}$. The column oven program started at a temperature of $35^{\circ} \mathrm{C}$ (held isothermally for 3 minutes), followed by heating up to $85^{\circ} \mathrm{C}$ at $5{ }^{\circ} \mathrm{C} / \mathrm{min}$ (also held isothermally for 3 minutes), and finally by a ramp up to $125{ }^{\circ} \mathrm{C}$ at $10{ }^{\circ} \mathrm{C} / \mathrm{min}$. The total program time was $20 \mathrm{~min}$. The injection temperature was $250{ }^{\circ} \mathrm{C}$ and the split ratio was 10:1. A Gazohrom-3101 gas chromatograph with a thermal conductivity detector was employed to determine the quantities of $\mathrm{H}_{2}, \mathrm{CO}$ and $\mathrm{CH}_{4}$ by using air as the carrier gas at a flow rate of $65 \mathrm{~mL} / \mathrm{min}$. A packed column (ID $3.5 \mathrm{~mm}$, length $2.5 \mathrm{~m}$ ), which operated at room temperature, was used for separation of gases. The injection volume was $2 \mathrm{~mL}$ and the relative standard deviation for parallel measurements for both GCs did not exceed $10 \%$ and $5 \%$, respectively. With a Shimadzu GC-2014, peaks of hydrocarbons of higher quantities could be observed. As calibration was not applicable to $\mathrm{C}_{2}$ and $\mathrm{C}_{3}$ hydrocarbons, their concentrations were determined using the $\mathrm{CH}_{4}$ peak area from a Gazohrom $3101 \mathrm{GC}$ as a reference, while the different thermal conductivities of the gases accounted for their different properties. To calculate the concentration of $\mathrm{C}_{2}$ and $\mathrm{C}_{3}$ hydrocarbon gases, it was assumed that the peak areas of the gases were directly proportional to their thermal conductivity at corresponding temperatures. Although this leads to a somewhat higher uncertainty, it also allowed us to obtain information on the concentrations of these gases which would have otherwise got lost. Consequently, the concentration values of these gases would more likely provide qualitative data about the respective trends throughout the experiments.

\section{Results and discussion}

\subsection{Gas analysis}

Tables 1 and 2 present the quantities of gases evolved at different test temperatures in different atmospheres as a function of temperature. The major gases evolved were $\mathrm{CO}, \mathrm{CO}_{2}, \mathrm{H}_{2}$, and $\mathrm{C}_{1}-\mathrm{C}_{3}$ hydrocarbons.

Campbell et al. [8], studying oil shale pyrolysis mechanisms from $25^{\circ} \mathrm{C}$ to $900{ }^{\circ} \mathrm{C}$, described it as a simplified two-step process of kerogen, during which the matter was transformed to bitumen and then bitumen to oil. In addition, the 


\begin{tabular}{|c|c|c|c|c|c|c|c|c|c|c|c|c|c|}
\hline \multirow{4}{*}{ 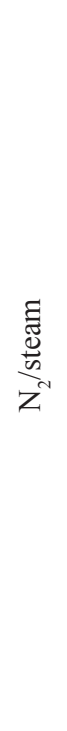 } & $\begin{array}{l}0 \\
0 \\
\text { त } \\
\text { n. }\end{array}$ & $\stackrel{+}{i}$ & ָై & $\bar{i}$ & $\exists$ & $\stackrel{\circ}{-}$ & $\stackrel{\circ}{\dot{m}}$ & $\vec{i}$ & 9 & $\stackrel{\Upsilon}{2}$ & $\overrightarrow{6}$ & $\vec{m}$ & กֶ. \\
\hline & $\begin{array}{l}0 \\
0 \\
0 \\
\hat{n} \\
\delta \\
\delta \\
i n\end{array}$ & $\vec{n}$ & $\stackrel{\vartheta}{\dot{ \pm}}$ & $\stackrel{n}{+}$ & $\vec{a}$ & 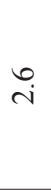 & 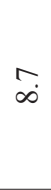 & $\stackrel{\circ}{i}$ & ?ु. & $\stackrel{\infty}{\underset{\forall}{\forall}}$ & $\underset{m}{\stackrel{5}{*}}$ & $\stackrel{b}{\sim}$ & $\tilde{o}$ \\
\hline & $\begin{array}{l}0 \\
0 \\
8 \\
i n \\
8 \\
8\end{array}$ & ir & $\stackrel{0}{\check{I}}$ & $\stackrel{0}{-}$ & $\stackrel{\circ}{\sim}$ & $\dddot{q}$ & $\stackrel{?}{+}$ & $\underset{0}{\infty}$ & $\stackrel{0}{\dot{r}}$ & $\stackrel{0}{\ddot{\lambda}}$ & $\stackrel{\infty}{\stackrel{ \pm}{ \pm}}$ & $\vec{\infty}$ & $\ddot{n}$ \\
\hline & 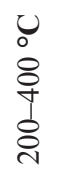 & $\overrightarrow{0}$ & $\stackrel{?}{-}$ & $\stackrel{0}{0}$ & $\ddot{0}$ & $\because$ & $\because$ & $\stackrel{0}{0}$ & $\stackrel{0}{0}$ & $\stackrel{0}{0}$ & $\tilde{0}$ & $\stackrel{0}{0}$ & $\stackrel{0}{0}$ \\
\hline \multirow{4}{*}{$z^{N}$} & $\begin{array}{l}0 \\
0 \\
\text { त } \\
\text { n }\end{array}$ & $\stackrel{\infty}{-}$ & $\begin{array}{l}\infty \\
i n\end{array}$ & $\stackrel{\gamma}{\dot{\sigma}}$ & 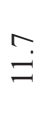 & $\stackrel{\circ}{0}$ & $\stackrel{\circ}{\dot{m}}$ & ळे & $\stackrel{\infty}{-}$ & $\stackrel{m}{\infty}$ & $\ddot{n}$ & $\cong$ & $\overrightarrow{0}$ \\
\hline & $\begin{array}{l}0 \\
0 \\
\circ \\
\hat{N} \\
\hat{n} \\
8 \\
0\end{array}$ & $\vec{n}$ & $\ddot{0}$ & $\stackrel{\vartheta}{\dot{\gamma}}$ & $\stackrel{+}{\bullet}$ & $\stackrel{n}{\sim}$ & $\grave{r}$ & $\stackrel{+}{r}$ & $\ddot{n}$ & $\stackrel{m}{n}$ & $\overrightarrow{\grave{\lambda}}$ & $\ddot{n}$ & $\stackrel{\jmath}{0}$ \\
\hline & \begin{tabular}{l}
0 \\
0 \\
8 \\
\hdashline \\
1 \\
8 \\
+
\end{tabular} & $\vec{n}$ & $\stackrel{\mathfrak{n}}{\Omega}$ & $\stackrel{?}{-}$ & $\ddot{n}$ & $\hat{o}$ & $\stackrel{9}{-}$ & $\ddot{n}$ & $\stackrel{6}{-}$ & $\overrightarrow{0}$ & $\stackrel{\circ}{\stackrel{2}{*}}$ & $\vec{m}$ & $\stackrel{+}{0}$ \\
\hline & $\begin{array}{l}0 \\
0 \\
8 \\
\& \\
\stackrel{+}{0}\end{array}$ & กั & $\tilde{i}$ & $\stackrel{0}{0}$ & $\stackrel{t}{0}$ & $\stackrel{0}{0}$ & $\stackrel{0}{0}$ & $\stackrel{0}{0}$ & $\because$ & $\stackrel{+}{0}$ & $\stackrel{+}{0}$ & $\stackrel{0}{0}$ & $\overrightarrow{0}$ \\
\hline & $\tilde{J}^{\mathscr{E}}$ & 8 & $e^{N}$ & $\Psi^{N}$ & $\widetilde{\Xi}^{+}$ & $\Xi_{U^{N}}^{+}$ & $\Psi^{I^{\circ}}$ & $\widetilde{U}^{\circ}$ & $\Psi^{\Psi^{\infty}}$ & $\begin{array}{l}0 \\
0 \\
0 \\
0 \\
0 \\
0 \\
0 \\
0 \\
0 \\
0 \\
0\end{array}$ & 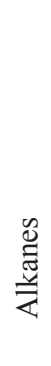 & 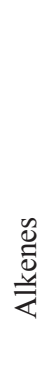 & 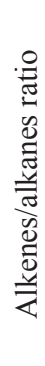 \\
\hline
\end{tabular}




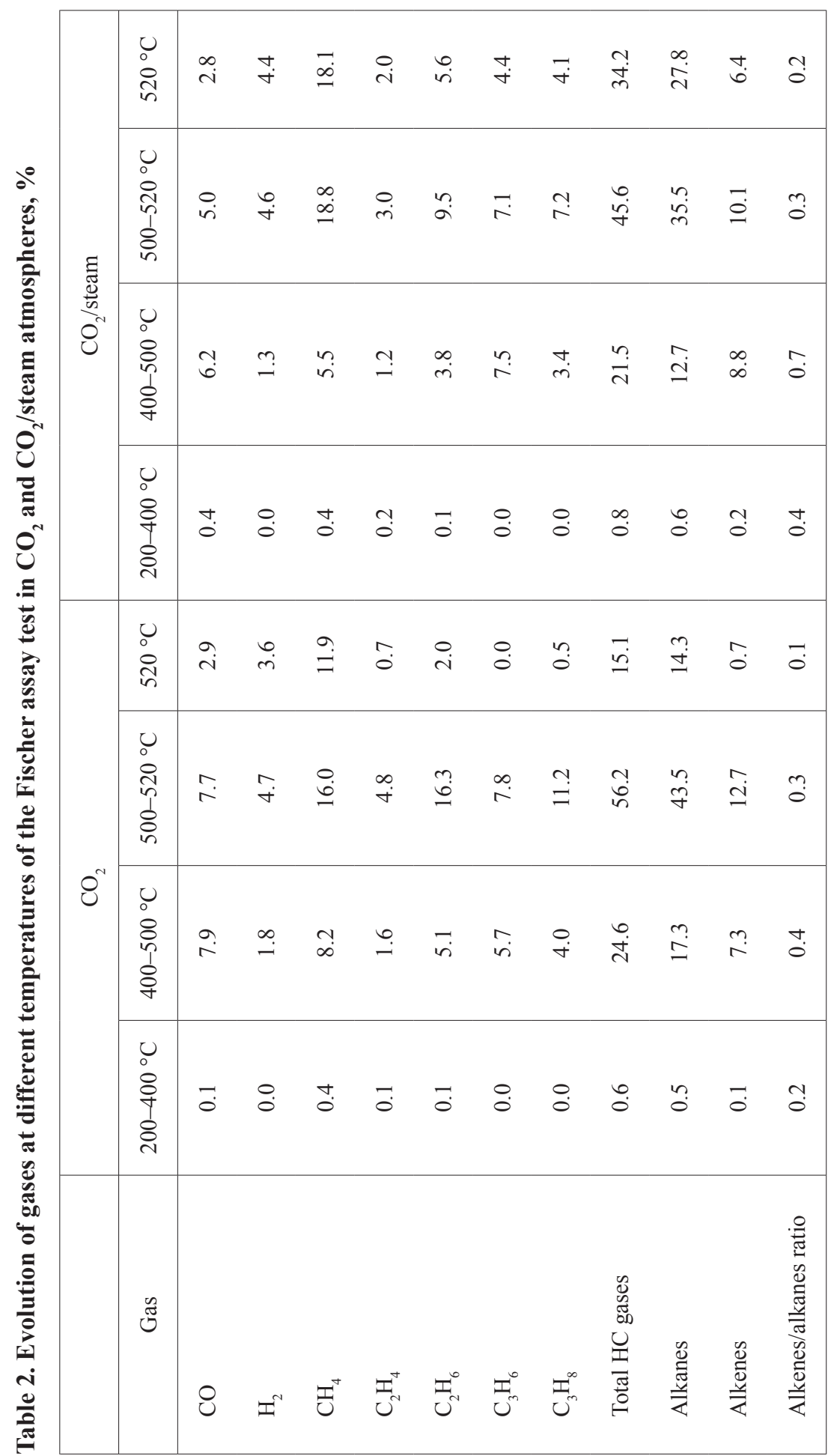


researchers suggested that only small amounts of non-condensable gases are produced during the process of conversion of kerogen to bitumen; however, during the conversion of bitumen to oil, the evolution of significant amounts of non-condensable gases takes place [8]. This can also be observed in the current work as seen from Table 1. Only traces of non-condensable gases were produced below $400{ }^{\circ} \mathrm{C}$ whereas above this temperature and up to $500{ }^{\circ} \mathrm{C}$ the main evolution of oil and gas can be observed.

The detailed analysis of evolution of hydrocarbon gases during the pyrolysis as a function of temperature in the presence of steam is shown in Figures 1-3. As seen from the figures, in all test environments the production of total $\mathrm{HC}$ gases, alkanes and alkenes was increased by increasing the retort temperature. Moreover, these figures indicate that the inclusion of steam in the $\mathrm{N}_{2}$ atmosphere caused an increase in the concentration of hydrocarbon gases, alkanes and alkenes in the gaseous pyrolysis products. These results agree with those of several other researchers' works [9-11]. Nazzal [12] suggested that the presence of steam in oil shale pyrolysis could play an important role in the exit gas composition because, in addition to having a high heat capacity, steam speeds up the pyrolysis process. Also, steam increases the heating value of gaseous products after condensation as a result of increase in the concentrations of $\mathrm{CO}$ and $\mathrm{H}_{2}$.

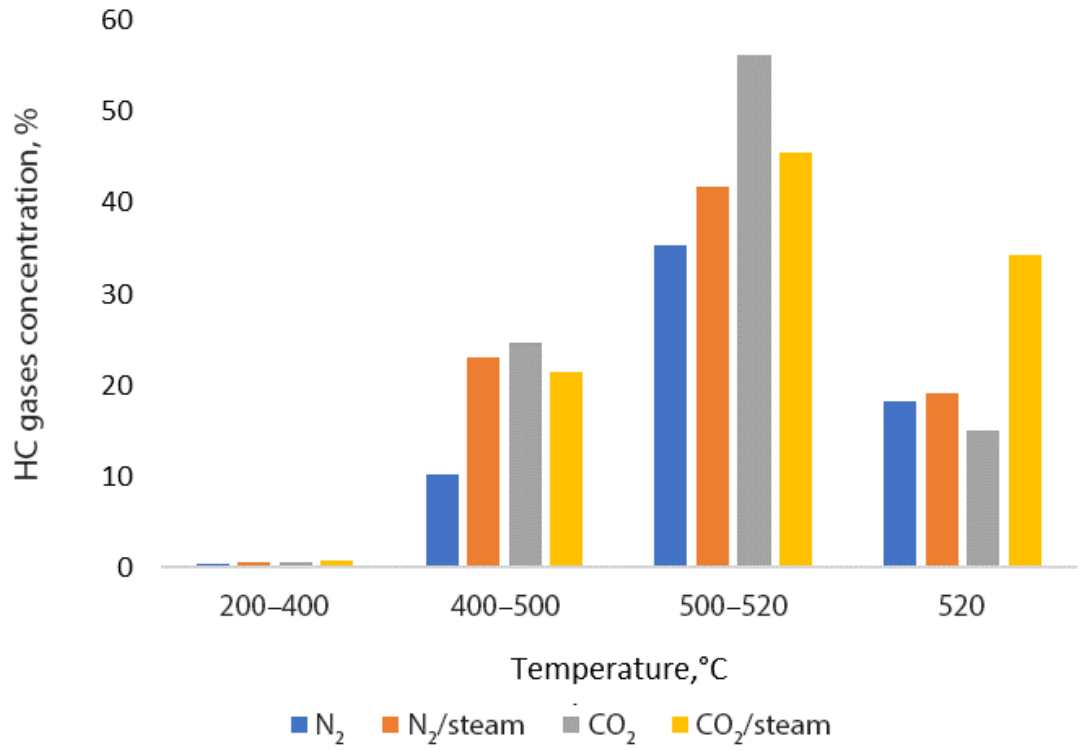

Fig. 1. Evolution of hydrocarbon gases during pyrolysis. 


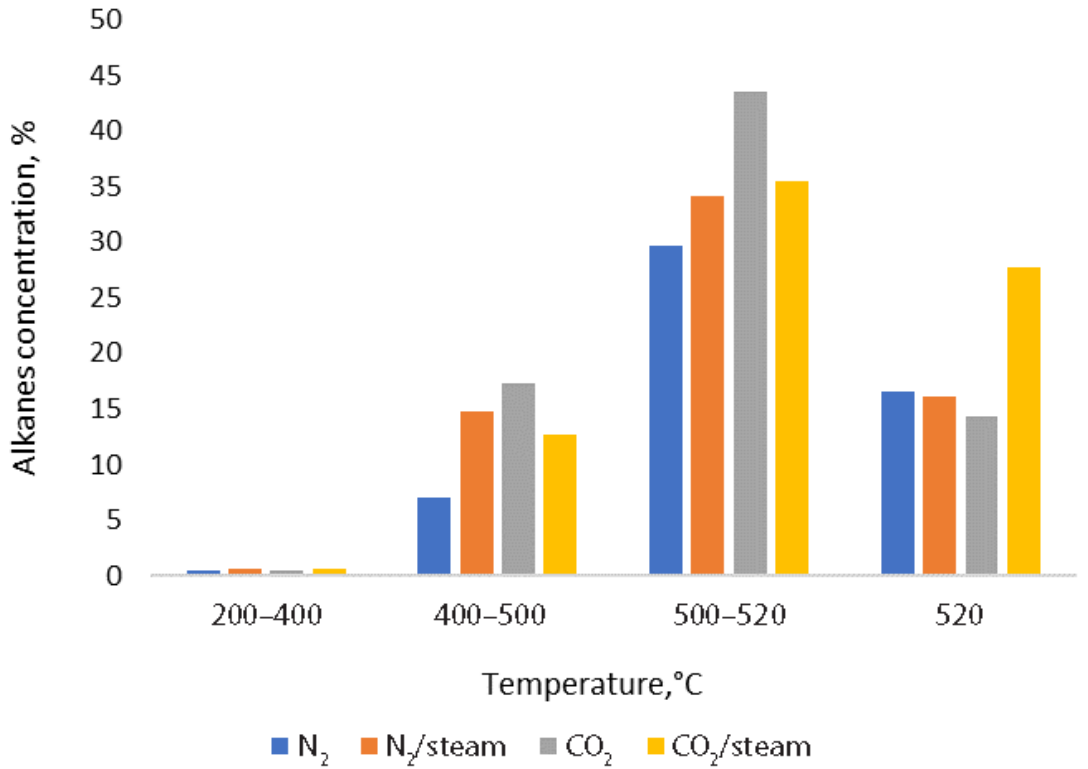

Fig. 2. Evolution of alkane gases during pyrolysis.

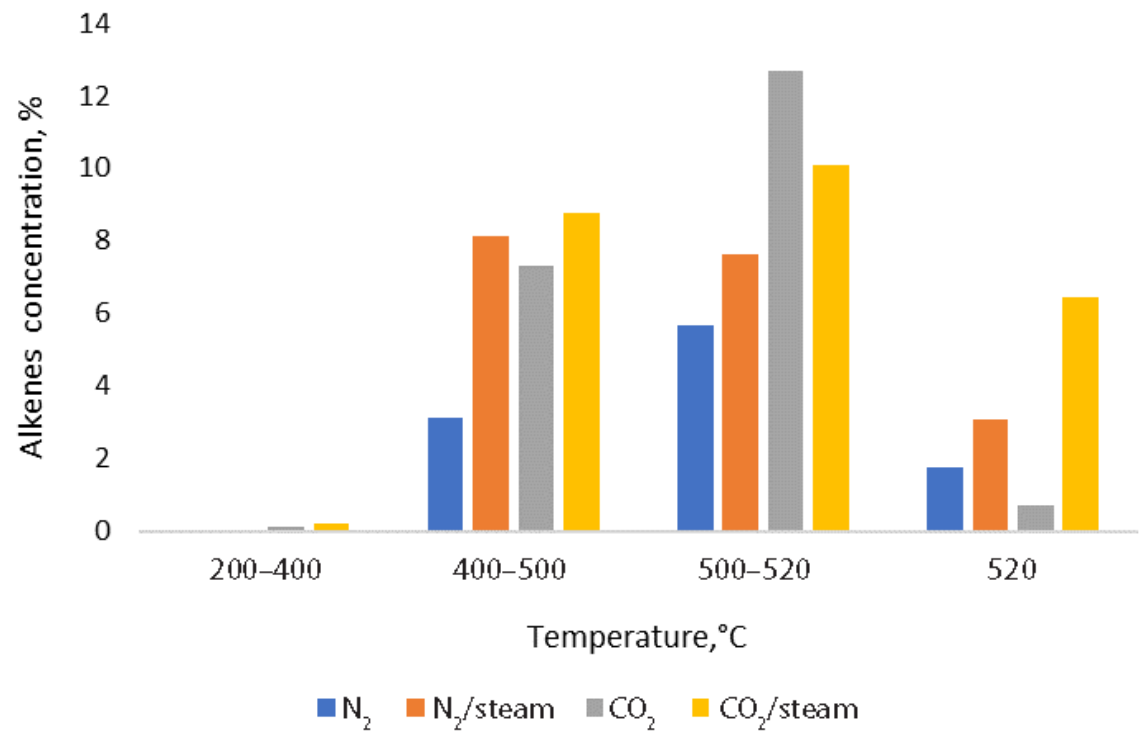

Fig. 3. Evolution of alkene gases during pyrolysis.

However, looking at the graphs more closely, it is obvious that steam has the opposite effects when injected into the $\mathrm{N}_{2}$ and $\mathrm{CO}_{2}$ environments. In the $\mathrm{N}_{2}$ atmosphere, steam enhanced the total amounts of $\mathrm{HC}$ gases, alkanes and 
alkenes. These results agree with Nazzal's findings [12] where a small increase in total $\mathrm{HC}$ gases and alkenes and a slight difference in alkanes production was observed between $400{ }^{\circ} \mathrm{C}$ and $520^{\circ} \mathrm{C}$ in the $\mathrm{N}_{2} /$ steam environment. As stated earlier, steam exerts a different effect in the $\mathrm{CO}_{2}$ atmosphere. In $\mathrm{CO}_{2}$, it caused a decrease in the total hydrocarbon and alkane gases production; however, the presence of steam initially increased the concentration of alkene gases (up to $400{ }^{\circ} \mathrm{C}$ ) and then reduced it as the evolution of oil began $\left(450{ }^{\circ} \mathrm{C}\right.$ ). Subsequently, steam decreased the concentration of alkenes at higher temperatures.

Table 1 also presents the alkenes/alkanes ratios for all tests during the HC gases evolution. The said ratio has been used to determine reaction mechanisms and indicates pyrolysis conditions $[11,13]$. Several researchers have suggested that an increase in the alkene/alkane ratio is a result of secondary cracking reactions $[9,11,12]$ and lower ratios are associated with coking reactions $[1,2]$. During pyrolysis the alkenes/alkanes ratio initially increased and then decreased. The highest values of the ratio may be due to the occurrence of secondary gas phase reactions in the temperature range of $400-500{ }^{\circ} \mathrm{C}$ where the evolution of oil and gas largely takes place. Moreover, these ratios were mostly higher in the pyrolysis with steam. Williams and Nazzal [9] suggested that even though steam increases the oil yield by decreasing the occurrence of secondary coking reactions, it also increases the alkenes/alkanes ratio, which means an increase in the taking place of secondary vapor phase cracking reactions.

Figure 4 exhibits the evolution of $\mathrm{CO}_{2}$ during pyrolysis in $\mathrm{N}_{2}$ and $\mathrm{N}_{2} /$ steam as a function of temperature. Even though studying $\mathrm{CO}_{2}$ evolution in the

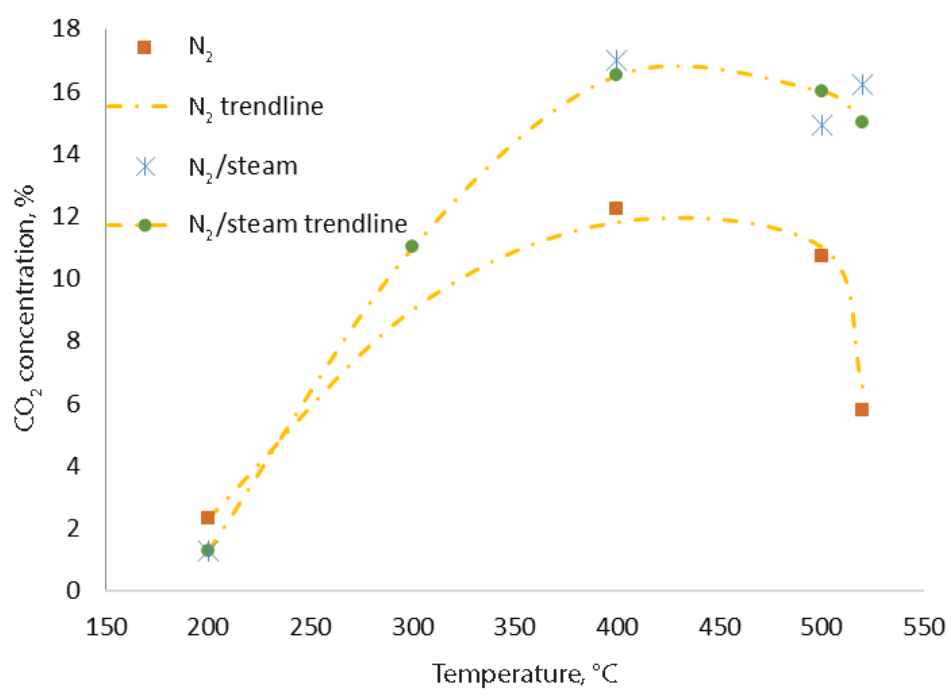

Fig. 4. Evolution of $\mathrm{CO}_{2}$ during pyrolysis as a function of temperature. 
tests in $\mathrm{CO}_{2}$ was not applicable, such measurements were made in the $\mathrm{N}_{2}$ and $\mathrm{N}_{2}$ /steam environments. It can be seen from the figure that the yield of $\mathrm{CO}_{2}$ was greatly increased in the run with steam. This could be a result of various reactions such as the water-gas shift reaction, mineral carbonate decomposition reactions as well as steam-hydrocarbon reactions. By increasing the pyrolysis temperature, the decomposition of mineral carbonates and production of water increase, which leads to the higher production of $\mathrm{CO}_{2}$ [12]. Looking at the yield of gases throughout the pyrolysis process (up to $500{ }^{\circ} \mathrm{C}$ ) indicates that $\mathrm{CO}_{2}$ made up the largest portion of the gaseous products. This may suggest that water vapor plays a certain role in oxidation reactions.

Williams and Nazzal [9] related the higher gas yield in $\mathrm{N}_{2} /$ steam to the higher $\mathrm{CO}_{2}$ concentration that is produced at higher temperatures and suggested that this is coupled with a series of reactions, namely the char-steam, water gas-shift, hydrocarbon steam and mineral carbonate-steam reactions.

Figures 5-7 compare the yields of $\mathrm{CO}, \mathrm{H}_{2}$ and $\mathrm{CH}_{4}$ during the decomposition of kerogen. Since the gas sampling was offline, it was not possible to find the precise peak temperature at which the evolution of gas took place. From the figures it can be perceived that the peak for carbon monoxide, hydrogen and methane evolution occurs at around $400-450{ }^{\circ} \mathrm{C}, 480-510{ }^{\circ} \mathrm{C}$ and $500{ }^{\circ} \mathrm{C}$, respectively. Huss and Burnham [14] also studied the gas evolution of different shale samples during pyrolysis in a reactor under an argon atmosphere over a temperature range of $25-950{ }^{\circ} \mathrm{C}$ at a heating rate of $2{ }^{\circ} \mathrm{C} / \mathrm{min}$. The researchers' findings show that the evolution of $\mathrm{CO}, \mathrm{H}_{2}$ and $\mathrm{CH}_{4}$ mostly happens at 425 $435{ }^{\circ} \mathrm{C}, 465{ }^{\circ} \mathrm{C}$ and $480-520{ }^{\circ} \mathrm{C}$, respectively. They associated this phenomenon with oil generation which occurred at the maximum rate at $430-435^{\circ} \mathrm{C}$.

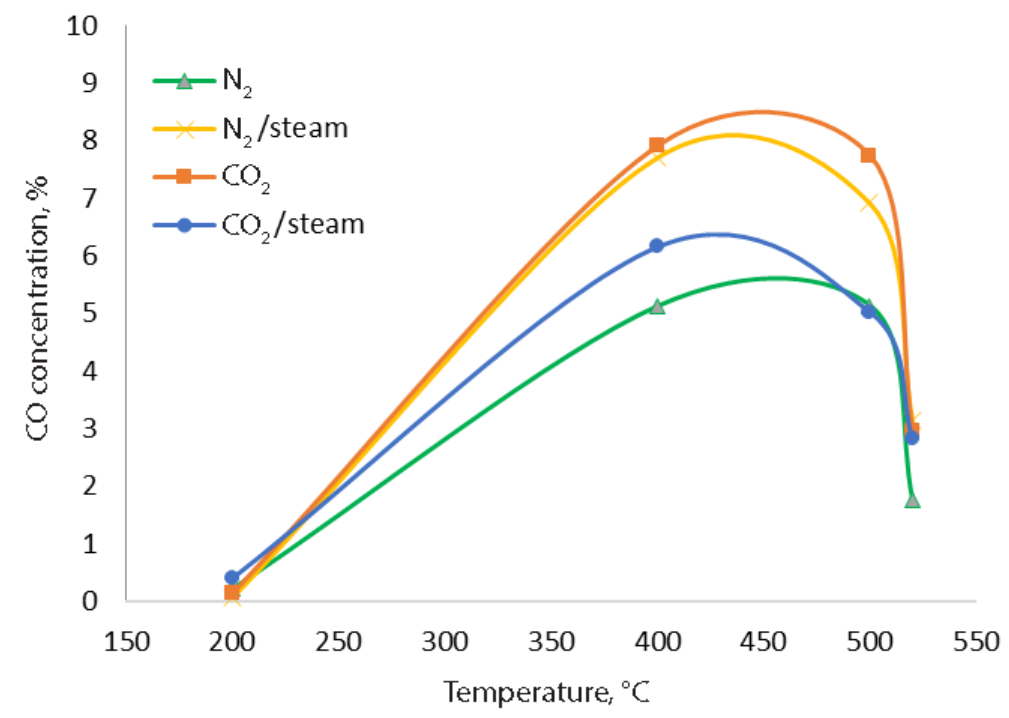

Fig. 5. Evolution of $\mathrm{CO}$ during kerogen decomposition. 


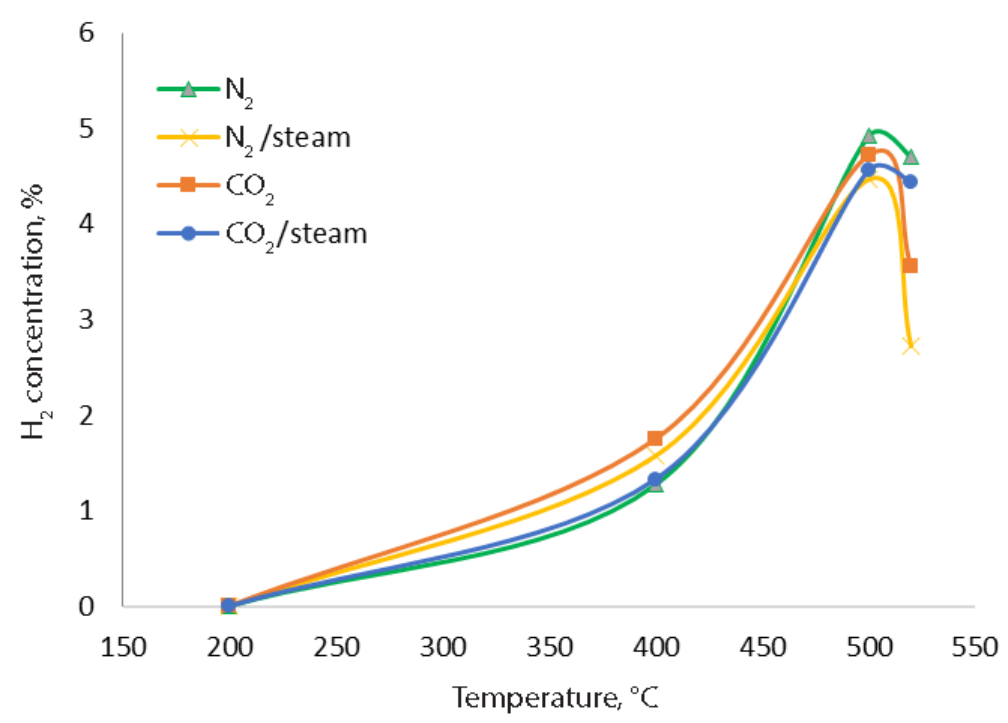

Fig. 6. Evolution of $\mathrm{H}_{2}$ during kerogen decomposition.

The experimental results of the current work revealed that in the presence of steam CO started to be produced at around $400{ }^{\circ} \mathrm{C}$ and had its highest content when the oil was about to be generated. It appears that the concentration of $\mathrm{CO}$ in $\mathrm{N}_{2}$ pyrolysis was lower than that in $\mathrm{N}_{2} /$ steam. That is partially because of the reactions that the produced water and injected steam initiate with the char to produce hydrogen and carbon monoxide. Also, in the water gas shift reaction, steam and $\mathrm{CO}$ produce hydrogen and $\mathrm{CO}_{2}$. These reactions have an obvious effect on the concentrations of $\mathrm{CO}$ and $\mathrm{H}_{2}$ in the retort. In addition, at higher temperatures, the concentration of $\mathrm{CO}$ is reduced and that of hydrogen increased. Also, it appears from the results of the test carried out in $\mathrm{N}_{2}$ that using $\mathrm{CO}_{2}$ as a sweep gas significantly increased the amounts of $\mathrm{CO}$ and $\mathrm{H}_{2}$ in the gaseous products. Generally, it was observed that steam injected into the $\mathrm{CO}_{2}$ atmosphere lowered the concentrations of $\mathrm{H}_{2}$ and $\mathrm{CO}$ in the pyrolysis gas but in the $\mathrm{N}_{2}$ atmosphere increased them.

Comparison of methane concentrations in the pyrolysis products indicates that its formation is higher in the $\mathrm{CO}_{2}$ atmosphere than in $\mathrm{N}_{2}$. It is apparent that the presence of steam yielded higher methane concentrations in $\mathrm{N}_{2}$ at all temperatures while in $\mathrm{CO}_{2}$ the methane formation only increased at higher temperatures. This can be explained by the reaction between steam and hydrocarbon gases in which oxygen and methane are formed:

$$
2 \mathrm{HC}+\mathrm{H}_{2} \mathrm{O} \rightarrow \mathrm{O}_{2}+\mathrm{CH}_{4}
$$




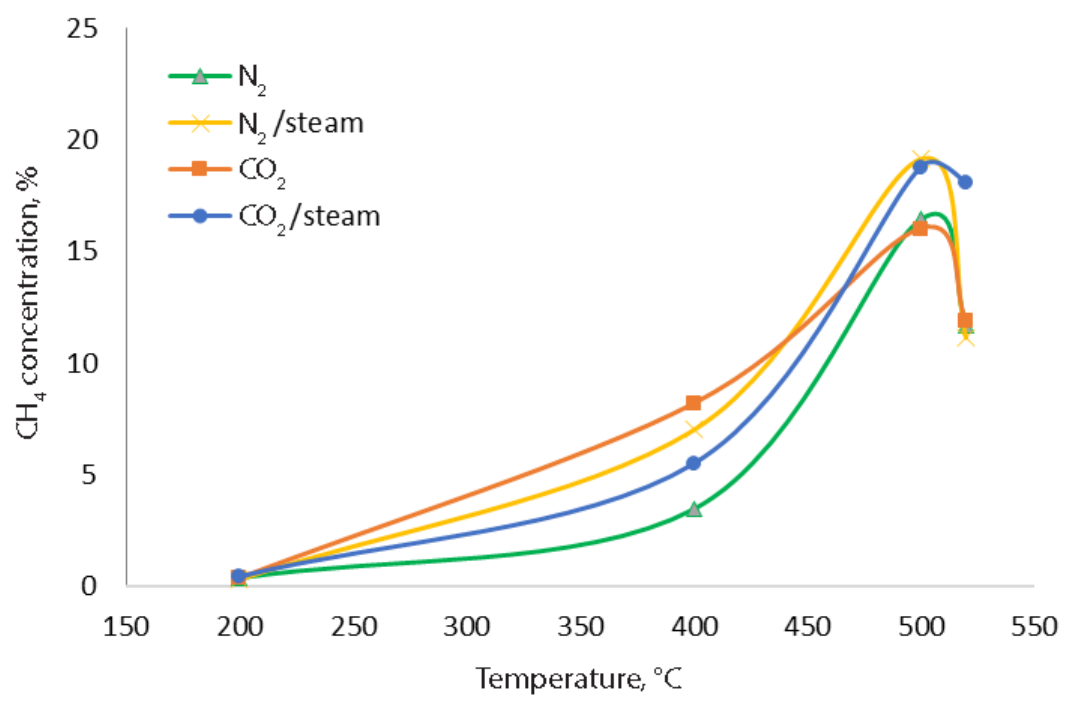

Fig. 7. Evolution of $\mathrm{CH}_{4}$ during kerogen decomposition.

It is for this reason that the yield of methane in pyrolysis with steam is higher.

It is worth noting that a sharp increase in the formation of said gases can be observed from about $400{ }^{\circ} \mathrm{C}$ onward. This is the approximate temperature at which bitumen is converted to oil and shale oil generation begins. As explained before, with increasing temperature the total concentration of $\mathrm{HC}$ gases increased and consequently, the formation of $\mathrm{H}_{2}$ and $\mathrm{CH}_{4}$ in the retort increased as well. During the last phase of the test, in which the retort temperature was held at $520{ }^{\circ} \mathrm{C}$ for 20 minutes, and due to the consumption of the shale sample over time, less hydrocarbons were produced, as a result of which the formation of methane decreased.

\section{Conclusions}

This research focused on the gaseous products of the pyrolysis of Estonian kukersite oil shale by using the Fischer assay method. The tests were conducted in four different atmospheres: $\mathrm{CO}_{2}, \mathrm{CO}_{2}$ /steam, $\mathrm{N}_{2}$ and $\mathrm{N}_{2}$ /steam. Gas chromatography was used to measure the amounts of the gases evolved. The analysis showed that more hydrocarbon gases were produced when steam was injected into $\mathrm{N}_{2}$. Conversely, the presence of steam caused a reduction in total hydrocarbon gases and alkane gases in the $\mathrm{CO}_{2}$ atmosphere. Moreover, the results indicated that in $\mathrm{CO}_{2}$ /steam the concentrations of $\mathrm{H}_{2}$ and $\mathrm{CO}$ were 
lowered by steam differently from the $\mathrm{CO}_{2}$ atmosphere. Furthermore, the alkenes/alkanes ratio, which is used to determine reaction mechanisms, first increased and then decreased. Analyzing the outcomes obtained from studying gases evolution during oil shale pyrolysis may contribute to the development and advancement of processes and technology to enhance the oil and gas yields from the retorting of oil shale.

\section{Acknowledgments}

This research was funded by the Estonian Research Council within the National Programme for Addressing Socio-Economic Challenges through R\&D (RITA), which is supported by the Estonian Government and the European Regional Development Fund.

\section{REFERENCES}

1. Wang, S., Liu, J., Jiang, X. Han, X., Tong, J. Effect of heating rate on products yield and characteristics of non-condensable gases and shale oil obtained by retorting Dachengzi oil shale. Oil Shale, 2013, 30(1), 27-47. https://doi. org/10.3176/oil.2013.1.04

2. Wang, S., Jiang, X., Han, X., Tong, J. Effect of residence time on products yield and characteristics of shale oil and gases produced by low-temperature retorting of Dachengzi oil shale. Oil Shale, 2013, 30(4), 501-516. https://doi.org/10.3176/ oil.2013.4.04

3. Baird, Z. S., Uusi-Kyyny, P., Järvik, O., Oja, V., Alopaeus, V. Temperature and pressure dependence of density of a shale oil and derived thermodynamic properties. Ind. Eng. Chem. Res., 2018, 57(14), 5128-5135. https://doi. org/10.1021/acs.iecr.7b05018

4. Ristic, N. D., Djokic, M. R., Konist, A., Van Geem, K. M., Marin, G. B. Quantitative compositional analysis of Estonian shale oil using comprehensive two dimensional gas chromatography. Fuel Process. Technol., 2017, 167, 241249. https://doi.org/10.1016/j.fuproc.2017.07.008

5. Mozaffari, P., Järvik, O., Baird, Z. S. Vapor pressures of phenolic compounds found in pyrolysis oil. J. Chem. Eng. Data, 2020, 65(11), 5559-5566. https://doi. org/10.1021/acs.jced.0c00675

6. Mozaffari, P., Baird, Z. S., Listak, M., Oja, V. Vapor pressures of narrow gasoline fractions of oil from industrial retorting of Kukersite oil shale. Oil Shale, 2020, 37(4), 288-303. https://doi.org/10.3176/oil.2020.4.03

7. Coburn, T. T. Eastern oil shale retorting: Gas evolution during pyrolysis of northeastern Kentucky shales. Energ. Source., 1983, 7(2), 121-150. https://doi. org/10.1080/00908318308908080 
8. Campbell, J. H., Koskinas, G. J., Gallegos, G., Gregg, M. Gas evolution during oil shale pyrolysis. 1. Nonisothermal rate measurements. Fuel, 1980, 59(10), 718-726. https://doi.org/10.1016/0016-2361(80)90027-7

9. Williams, P. T., Nazzal, J. M. Polycyclic aromatic compounds in shale oils: Influence of process conditions. Environ. Technol. (United Kingdom), 1998, 19(8), 775-787. https://doi.org/10.1080/09593331908616734

10. Wang, S., Jiang, X., Han, X., Tong, J. Effect of retorting temperature on product yield and characteristics of non-condensable gases and shale oil obtained by retorting Huadian oil shales. Fuel Process. Technol., 2014, 121, 9-15. https://doi. org/10.1016/j.fuproc.2014.01.005

11. Williams, P. T., Ahmad, N. Influence of process conditions on the pyrolysis of Pakistani oil shales. Fuel, 1999, 78(6), 653-662. https://doi.org/10.1016/S00162361(98)00190-2

12. Nazzal, J. M. Gas evolution from the pyrolysis of Jordan oil shale in a fixedbed reactor. J. Therm. Anal. Calorim., 2001, 65(3), 847-857. https://doi. org/10.1023/A:1011936401407

13. Williams, P. T., Nazzal, J. M. Polycyclic aromatic compounds in oils derived from the fluidised bed pyrolysis of oil shale. J. Anal. Appl. Pyrol., 1995, 35(2), 181-197. https://doi.org/10.1016/0165-2370(95)00908-9

14. Huss, E. B., Burnham, A. K. Gas evolution during pyrolysis of various Colorado oil shales. Fuel, 1982, 61(12), 1188-1196. https://doi.org/10.1016/00162361(82)90018-7 